\title{
Determinative ratios of a rheological model of a discrete medium with a variable angle of internal friction
}

\author{
O.A. Dorofeyev ${ }^{1 *}$, V.V. Kovtun ${ }^{1}$ \\ Khmelnytskyi National University, Ukraine \\ *E-mail: sa_dor@ukr.net
}

\begin{abstract}
The article deals with determining ratios of a rheological model of a discrete medium with a variable angle of internal friction, which reflect the characteristic features of deformation of a discrete material: the influence of internal Coulomb friction and the manifestation of dilatancy at all stages from the beginning of loading to the onset of the limit state.

The relations are formulated in the form adopted in the theory of plastic flow of material with a variable flow surface. This allowed us to use a well-tested apparatus of the theory of rigidity of a solid body to describe the process of deformation of a discrete material.

To formulate the relations, new concepts of stresses and strains occurring on special conjugate planes, which are convenient for describing the deformation of a discrete material, have been introduced.

The values of its variable parameters necessary for the use of the model in the en gineering calculations are proposed to determine by the results of special laboratory tests of macro-samples of a specific material for biaxial compression in conditions of flat deformation.
\end{abstract}

Key words: discrete environment; internal coulomb friction; dilatation.

\section{Introduction}

The tasks of Engineering Mechanics need to describe the stress-strain state of interacting objects of different classes: solids; physically discrete materials; liquids; gases, etc. Appropriate rheological models are used for this purpose. These are well-tested models of the theory of elasticity or the theory of plasticity of a rigid deformable body; models of hydromechanics of liquids; models of gas aerodynamics. A similar model for discrete material has not yet been developed. The most promising direction for the development of such a model is considered to be a modification of the plastic flow model of a rigid deformable body, which will take into account the experimentally established differences in the laws of deformation of discrete materials and solids [1]. A rheological model of plastic flow, reflecting the fundamental features of deformation of a discrete material in the limiting stage, was proposed by Drucker and Prager [2]. However, this model, like all plastic flow models, describes the material deformation process only in the limit state. Therefore, in formulating the relations of the generalized model of the discrete medium, one can use the apparatus of the theory of plastic flow of material that is "changing" - material with a variable surface of the flow [3]. This allows us to describe the deformation of the discrete material in the pre-boundary and boundary states from a single position. The purpose of the article is to substantiate the determining relations of a generalized rheological model of a discrete material, which would reflect the features of its deformation both in the pre-boundary and boundary states.

\section{State of the problem}

Physically discrete materials (sand, gravel, grainy and granular materials) in Engineering Mechanics occupy an intermediate position between rigid deformable bodies and liquids. Like solids, they resist the action of external loading due to internal friction forces in the compressive stress zone, and like liquids they do not retain the initial equilibrium shape without external constraints because they do not perceive tensile stresses. In engineering, discrete materials interact with structural elements: the foundations of structures, retaining walls, 
vehicles, and elements of process equipment related to the processing of discrete materials. To calculate these structures a special rheological model is required that adequately describes the features of deformation of the discrete material in its interaction with the elastic elements of the structure.

The analysis of the results of famous studies of the laws of materials' deformation [4] leads to the conclusion that the determining relations of such a model must first of all reflect the following features of their deformation:

1) the influence of internal dry friction on the deformation process of the material not only at the boundary but also at the pre-boundary stage;

2) manifestation of dilatation, - the occurrence of volumetric deformations during displacements at all stages of deformation;

3) a significant dependence of nonlinear physical stress-strain relationships on the type of stress-strained state. These features can be most fully taken into account when using the apparatus of the theory of plastic flow of materials with a variable surface of the flow when formulating model relationships. The nature of this surface is established by the results of laboratory tests of material samples under conditions of flat deformation [5], since this rheological model is proposed precisely to describe the flat-deformed state of a discrete medium.

\section{The starting position of the model}

1. The discrete environment is considered to be quasi-integral. This allows us to use well-tested apparatus of mechanics of deformable body to describe its stress-strained state, naturally, taking into account the fundamental differences of the laws of deformation of discrete and solid materials. In classical plasticity theory, after reaching the elastic limit complete deformations $\{\varepsilon\}$ are represented as the sum of elastic $\left\{\varepsilon^{e}\right\}$ and residual plastic $\left\{\varepsilon^{p}\right\}$ deformation, $\{\varepsilon\}=\left\{\varepsilon^{e}\right\}+\left\{\varepsilon^{p}\right\}$, or $\{d \varepsilon\}=\left\{d \varepsilon^{e}\right\}+\left\{d \varepsilon^{p}\right\}$. Elastic deformations $\left\{\varepsilon^{e}\right\}$ of discrete materials arise due to compression of grains and make up a small part of total deformations $\{\varepsilon\}$. The residual (plastic) deformations $\left\{\varepsilon^{p}\right\}$ of a discrete material are considered to be deformations $\left\{\varepsilon^{s}\right\}$ caused by the mutual slip of particles. These deformations arise from the very beginning of loading of a discrete material and determine all features of its deformation. The proportion $\left\{\varepsilon^{s}\right\}$ of total deformations $\{\varepsilon\}$ increases as they approach the limit state in which they become determinative and are associated with the plastic flow of the medium. In most cases, we will neglect elastic deformations $\left\{\varepsilon^{e}\right\}$.

2. The discrete medium is considered to be a medium with significant internal friction, not only in the boundary but also in the pre-boundary state. The boundary condition is described by the Mohr-Coulomb condition and is realized on the planes of boundary equilibrium, at which the total stress $P_{z p}$ deviates from the normal at the maximum angle - the angle of internal friction $\varphi$. On these planes the ratio of the boundary stresses $\tau_{\text {гр }} / \sigma_{\text {гр }}=\operatorname{tg} \varphi$. In the pre-boundary state, the planes of boundary equilibrium correspond to paired conjugate planes of maximum deviation - planes with the maximum stress ratio $\tau_{\rho} / \sigma_{\rho}=\operatorname{tg} \rho$. In the limiting deformation stage, when the angle $\rho$ becomes equal to the internal friction angle, $\rho=\varphi$, they pass into the plane of boundary equilibrium. Therefore, the maximum deviation angle $\rho$ can be considered as a variable parameter of a generalization model that describes both pre-boundary and boundary deformation of discrete material from a single position. The assumption that the deformation of a discrete medium is related to the ratio of stresses $\tau / \sigma=\operatorname{tg} \rho$ rather than magnitude $\tau_{\max }$, as it is accepted in the theory of plasticity of a solid, reflects the first fundamental feature of discrete materials that is the influence on the process of their deformation of internal friction.

The second fundamental feature of the deformation of discrete materials is the manifestation of the dilatancy effect which is taken into account by the fact that the determining proportions of the model at the preboundary stage of deformation are written in a similar way to the limiting one[5]. They correlate the ratio of strain increases $d \varepsilon_{\rho}^{s} / d \vartheta_{\rho}^{s}$ with the ratio of stresses $\tau_{\rho} / \sigma_{\rho}$ on the joined planes of the largest deviation in the form:

$$
\frac{d \varepsilon_{\rho}^{s}}{d \vartheta_{\rho}^{s}}=f\left(\frac{\tau_{\rho}}{\sigma_{\rho}}\right),
$$

where $\vartheta_{\rho}^{s}$ is the displacement between the plane of the greatest deviation and the main plane.

Formula of deterministic relationships takes into account both organically related features of the deformation of discrete materials that is the effect of internal friction and the manifestation of dilation. The third 
fundamental feature of the discrete materials is a significant dependence of the laws of their deformation on the type of stress-strained state is taken into account that the nature of these laws is established by the results of laboratory tests of macro-samples of material under conditions of flat deformation. It is for this stress-strained state that the model is proposed and original laboratory equipment has been created [6]. In order to record the determining relation of the model in the formula (1), a new concept, convenient for describing the boundary state of the discrete material of conjugate planes is offered. These are paired planes with the same magnitude of the stress ratio $\tau / \sigma=\operatorname{tg} \rho$. The class of conjugates include the largest deviation planes for which $\tau_{\rho} / \sigma_{\rho}=\operatorname{tg} \rho_{\text {мax }}$, as well as the principal planes $(\rho=0)$. The estimation of the stressed state due to the strain on the coupled planes is analysed in detail in [7] and the deformed state is described in [8].

\section{Justification of the defining relations of a generalized model of a discrete medium}

Model definitions must reflect the fundamental features of the deformation of a discrete material at all stages of loading from a single position. The nature of the deformations of the discrete material in the boundary and in the pre-boundary states is the same - the deformations $\left\{\varepsilon^{s}\right\}$ result from the mutual slip of particles. This allows us to formulate the determinative relations of the rheological model of a discrete material in a similar manner to the correlation of the theory of plastic flow of a material with a variable yield surface [3]. eterminants of plastic flow models are introduced either directly in the form of tensor functions that relate the components of the strain rate tensor to the stress tensor components [9], [10], or by specifying a potential function whose derivatives determine strain rates [11], [12 ], [13].

Taking into account experimentally established features of deformation of discrete materials [6], we have formulated deterministic relations in the form of an invariant dependence between the ratio of stresses and the ratio of the rates of deformation in the conjugate planes of the largest deviation:

$$
\frac{\tau_{\rho}}{\sigma_{\rho}}=-\tilde{\mu} \frac{d \varepsilon_{\rho}^{s}}{d \vartheta_{\rho}^{s}}
$$

where $\tilde{\mu}$ is the variable parameter.

Or in the form of a relationship between the principal stresses $\sigma_{1}, \sigma_{2}$ and the increments of deformation $d \varepsilon_{2}^{s}, d \varepsilon_{1}^{s}$ on the principal planes that are coupled:

$$
\frac{\sigma_{1}}{\sigma_{2}}=\xi=-\tilde{k} \frac{d \varepsilon_{2}^{s}}{d \varepsilon_{1}^{s}},(\tilde{k}-\text { variable parameter })
$$

Dependence (2) can be considered as a relation of a model of a discrete medium with a variable angle of internal friction:

$$
\operatorname{tg} \rho=-\tilde{\mu} \cdot \operatorname{tg} \psi
$$

where $\rho$ is the angle between full strain $P_{\rho}$ and normal to the conjugate plane of maximum deflection; $\psi$ is the angle between the strain increment vector and the normal to the plane of maximum deflection.

In the limited state $\rho=\psi=\varphi, \tilde{\mu}=1$ and then expression (2) coincides with the specified Drucker Prager model relation [2], developed to describe the deformation in the limited stage.

The definitions (2) - (4) are written in invariant form. To determine the same components of the strain increases' tensor $\left\{d \varepsilon^{s}\right\}$, we introduce, as it is customary in the theory of plastic flow, the load function $F\left(\{\sigma\}, \chi_{i}\right)$ which derivatives of the stress tensor components are components of the strain increases' tensor $\left\{d \varepsilon^{s}\right\}:$

$$
\left\{d \varepsilon^{s}\right\}=\frac{d F\left(\{\sigma\}, \chi_{i}\right)}{d\{\sigma\}}
$$


Since the discrete environment is considered as "hardening" in the deformation process, the load function includes the hardening parameters $\chi_{i}$. The nature of the function is determined by the results of laboratory testing of macro samples of the material. In order to determine the nature of the load function, it is necessary to address the fundamental questions regarding the choice of reinforcement parameters $\chi_{i}$. Only one hardening parameter is introduced in the theory of plasticity of a rigid body, since plastic deformation under the SaintVenant condition is associated only with the magnitude of the maximum tangent stress $\tau_{\max }$, that is, with the radius $\mathrm{R}$ of the Mohr's circle (Fig. 1, a). The deformation of the same discrete medium according to relation (1) occurs depending on the ratio of stresses $\tau_{\rho} / \sigma_{\rho}=\operatorname{tg} \rho$, that is depending on the value of the alternating angle of internal friction $\rho$. To determine the angle $\rho$, as one can see from Fig. 1, b, two parameters are required radius $\mathrm{R}$ of the Mohr's circle and the abscissa of the center $\sigma_{0}$ :

$$
\frac{R}{\sigma_{0}}=\sin \rho
$$

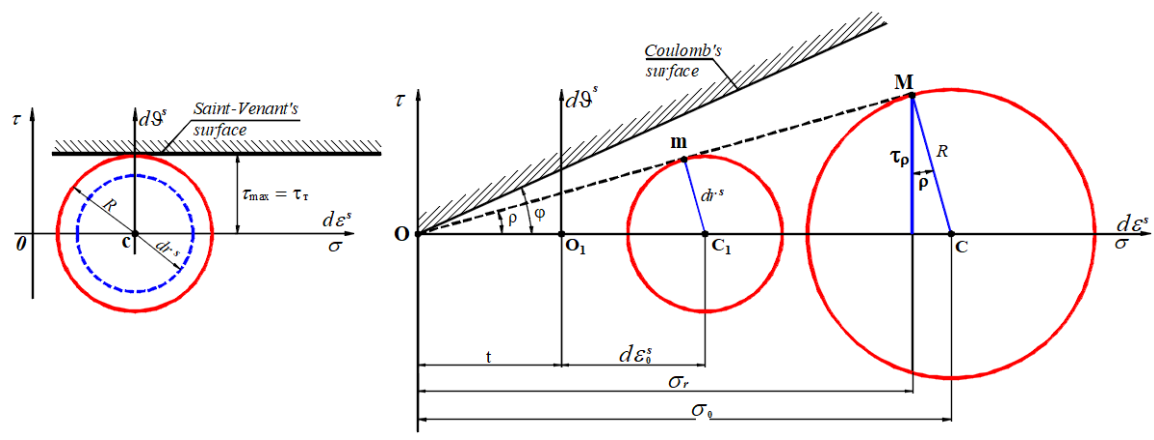

a)

b)

Fig. 1 Comparison of circle diagrams:

a) circle diagrams of the stresses and increases of deformation of a rigid plastic body

b) circle diagrams of limited stresses and increaeses of deformations of discrete material

Therefore, the load function of the discrete environment model should include two hardening parameters. They can be demonstrated through the parameters of the pie chart $d \varepsilon^{s}-d \vartheta^{s}$ (Fig. 1, b) by the formula:

$$
\chi_{1}=\int_{(\sigma)} d r^{s} ; \chi_{2}=\int_{(\sigma)} d \varepsilon_{0}^{s},
$$

where $d r^{s}$ is the radius of the pie chart; $d \varepsilon_{0}^{s}$ - abscissa of the diagram center.

Integration is done along the load path. If the path from the beginning of loading to a fixed value of stresses $\left\{\sigma_{*}\right\}$ is known, then the hardening parameters allow us to determine the level of deformation achieved during loading.

$$
\begin{aligned}
& \chi_{1}=\int_{0}^{\left\{\sigma_{*}\right\}} d r^{s}=r_{*}^{s}, \\
& \chi_{2}=\int_{0}^{\left\{\sigma_{*}\right\}} d \varepsilon_{0}^{s}=\varepsilon_{0^{*}}^{s},
\end{aligned}
$$

where $r_{*}^{s}=0,5\left(\varepsilon_{1}^{s}-\varepsilon_{2}^{s}\right)$ i $\varepsilon_{0^{*}}^{s}=0,5\left(\varepsilon_{1}^{s}+\varepsilon_{2}^{s}\right)$.

The nature of the load function is determined by the results of special studies. Considering the essential dependence of the laws of deformation of discrete materials on the type of stress-strained state, establishing a type of load function unique to any stress state is too complicated, practically impossible task. In case of flat deformation, for which the model is proposed, the problem is simplified. Let's present a load function that describes the process of flat boundary deformation of a discrete material as the sum of two functions: $F_{1}\left(\operatorname{tg} \rho, \chi_{1}\right)$ one that reflects the law of form change and $F_{2}\left(\sigma_{0}, \chi_{2}\right)$ one that describes the law of volume change. 
Taking into account the definitions (2), (3), the form function can be demonstrated by the formula:

$$
F_{1}=f\left(\frac{\tau_{\rho}}{\sigma_{\rho}}\right)_{\sigma_{0}=\text { const }}+\chi_{1}=0, \text { or } F_{1}=f\left(\frac{\sigma_{1}}{\sigma_{2}}\right)_{\sigma_{0}=c o n s t}+\chi_{1}=0
$$

and the volume change feature:

$$
F_{2}=f\left(\sigma_{0}\right)_{\xi=\text { const }}+\chi_{2}=0
$$

In the above formulas values $\tau_{\rho}, \sigma_{\rho}$ are the strains acting on the plane of maximum deviation, which at all times coincide with the directions of the characteristics of the field of stresses, and are inclined to the main directions at an angle $\pi / 4 \mp \rho / 2$. In the transition to the limited state $(\rho=\varphi)$, they coincide with the planes of the boundary equilibrium. The line inscriptions $\sigma_{0}=$ const, $\xi=$ const emphasize that the nature of the functions and the corresponding parameters are determined by the results of special tests. The law of formchange $F_{1}$ is established by the results of tests of macrosamples of discrete material under conditions of flat deformation with constant stress $\sigma_{0}$ and changes in relation $\xi=\sigma_{1} / \sigma_{2}$ to the onset of the limited state $\left(\xi=\xi_{\Gamma \mathrm{p}}\right)$.

The experimental graphs of the load function $F_{1}(9)$ are a dense bundle of curves $\tau_{\rho} / \sigma_{\rho}=f\left(\vartheta_{\rho}^{s}\right)$ at $\sigma_{0}=$ const . Multiplicity of these curves in the studied range can be sufficiently replaced by the one shown in Fig. 2 curve, which essentially describes the law of form's change of discrete material.

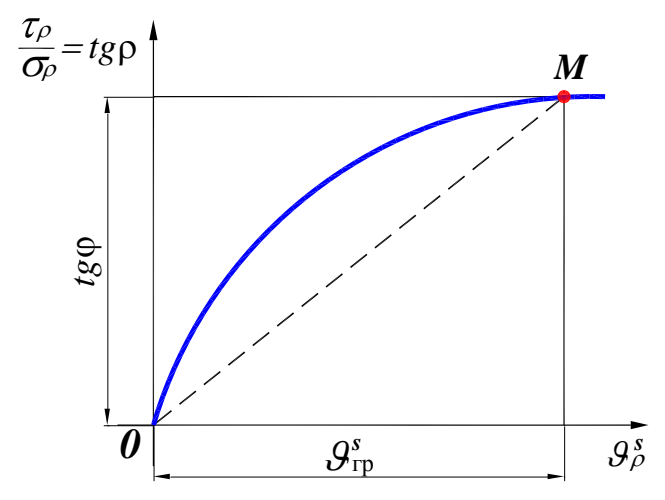

Fig. 2. Graphic representation of the law of change

The hardening parameter $\chi_{1}$ that is included in the load function $F_{1}$ reflects its nature and allows to determine the level of deformation $\vartheta_{\rho}^{s}$ corresponding to a fixed stressed state achieved during loading $\left\{\sigma_{*}\right\}$. According to (7):

$$
\chi_{1}=r_{*}^{s}, \text { a } \vartheta_{\rho}^{s}=r_{*}^{s} \cos \rho=\chi_{1} \cos \rho
$$

The experimental curves $\operatorname{tg} \rho=f\left(\vartheta_{\rho}^{s}\right)$ are well approximated by power or fractional-linear functions. The most convenient for practical use is the function:

$$
\frac{\tau_{\rho}}{\sigma_{\rho}}=\operatorname{tg} \rho=\frac{2 \vartheta_{\rho}^{s} \cdot \operatorname{tg} \varphi}{a+\vartheta_{\rho}^{s}}
$$

where $\varphi$ is the angle of internal friction; $a=\vartheta_{г \mathrm{p}}^{s}-$ the value of deformation $\vartheta_{\rho}^{s}$ at the time of transition to the limit state.

It is easy to verify that, when the limited state occurs $\vartheta_{\rho}^{s}=\vartheta_{\text {гр }}^{s}, \operatorname{tg} \rho=\operatorname{tg} \varphi$, expression (11) coincides with the Coulomb condition: 


$$
\frac{\tau_{\rho}}{\sigma_{\rho}}=\operatorname{tg} \varphi
$$

Therefore, the formulation of the law of shape-shifting in the form of a fractional-linear function (11) provides a smooth transition from the description of pre-boundary deformation of a discrete material to a boundary one. The more difficult task is to establish the nature of function $F_{2}(10)$, which describes the pattern of volume change. Its character is established by the results of laboratory tests of macro-samples of the material for biaxial compression under the conditions of flat deformation with a constant ratio of principal stresses $\xi$ and variable average stress $\sigma_{0}$. Total volumetric deformations $\varepsilon_{0}$ can be represented as the sum of deformations $\varepsilon_{0}^{r}$ which, as it is customary in the mechanics of a rigid deformable body, depend on the value of the average stress $\sigma_{0}$, and the dilatancy component $\varepsilon_{0}^{\text {म }}$ related to the stress ratio $\tau_{\rho} / \sigma_{\rho}=\operatorname{tg} \rho$, or $\sigma_{1} / \sigma_{2}=\xi$ :

$$
\varepsilon_{0}=\varepsilon_{0}^{r}+\varepsilon_{0}^{\text {Д }} .
$$

Fig. 3 shows the characteristic curves $\varepsilon_{0}=f\left(\sigma_{0}\right)$ obtained when testing the samples of dry quartz sand for biaxial compression under the conditions of constant stress ratio $\xi=$ const and increase of the average compressive stress $\sigma_{0}$.

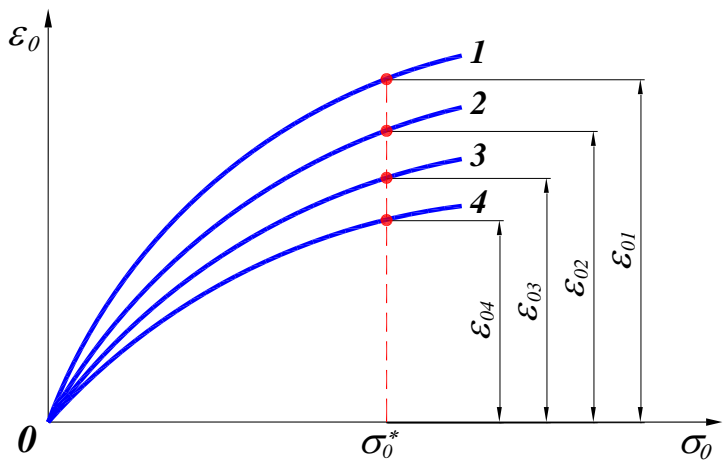

Fig. 3. Changing the volume deformation in tests with constant stress, $\xi=$ const

Curve 1 describes the pattern of volumetric deformation under hydrostatic isotropic compression $\left(\sigma_{1}=\sigma_{2}, \xi=1\right)$. With this stress state, deformations do not occur, and the curvature of the graph $\varepsilon_{0}^{r}-\sigma_{0}^{r}$ is explained by the destruction of the material in the contacts of the particles and the associated change in its structure.

Most often, the dependence $\varepsilon_{0}^{r}=f\left(\sigma_{0}^{r}\right)$ is approximated by a power function of the formula:

$$
\varepsilon_{0}^{r}=A \sigma_{0}^{\alpha}
$$

where $A$ and $\alpha$ are experimental parameters.

Curves $2,3,4$, which correspond to increasing values of stress ratios $\xi_{2}>\xi_{3}>\xi_{4}$, increasingly deviate from curve 1 . These deviations are related to the stress ratio $\xi$, value of which according to (3) takes into account the effect of dilatancy. That is, deviation from curve 1 can be regarded as the dilatant component $\varepsilon_{0}^{\text {A }}$ of the volume deformation (12) caused by the mutual slip of particles $\varepsilon_{0}^{s}$;

$$
\varepsilon_{0}^{\text {Д }}=\varepsilon_{0}^{s}=\varepsilon_{0 i}-\varepsilon_{0}^{r} .
$$

The deformations $\varepsilon_{0}^{\text {Д }}$ are easily determined from the graphs shown in Fig. 3. The figure shows a vertical line that corresponds to a fixed value of the average voltage $\sigma_{0}^{*}$. The deformation value $\varepsilon_{0}^{s}$ for the selected value $\xi$ is defined as the difference of the ordinates of the corresponding curve and curve $1-\varepsilon_{02}^{s}=\varepsilon_{02}-\varepsilon_{01}$; $\varepsilon_{03}^{s}=\varepsilon_{03}-\varepsilon_{01} ; \varepsilon_{04}^{s}=\varepsilon_{04}-\varepsilon_{01}$ 


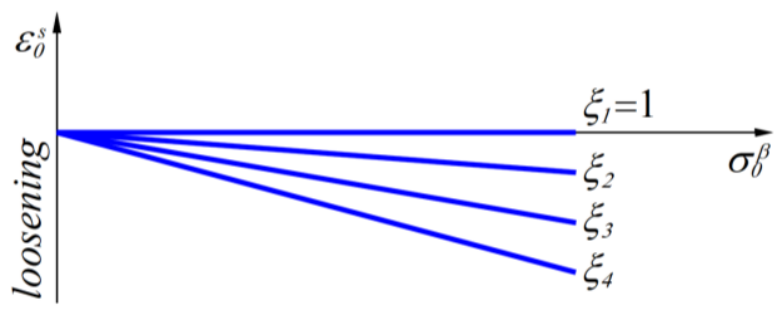

Fig. 4. Graphs $\varepsilon_{0}^{s}=B \sigma_{0}^{\beta}$ in functional coordinates

The analysis of the results of the experimental studies showed that the curves $\varepsilon_{0}^{s}=f\left(\sigma_{0}\right)_{\xi=c o n s t}$ can also be approximated by power equation $\varepsilon_{0}^{s}=B \sigma_{0}^{\beta}$, which is confirmed by the graphs constructed in the functional coordinates $\varepsilon_{0}^{s}, \sigma_{0}^{\beta}$ (Fig. 4). The power equations in these coordinates are transposed into straight lines.

Taking into accout that, according to (8) $\varepsilon_{0}^{s}=\chi_{2}$, we present the load function $F_{2}=f\left(\sigma_{0}\right)_{\xi=\text { const }}+\chi_{2}$ in the formula:

$$
\varepsilon_{0}=A \sigma_{0}^{\alpha}-B \sigma_{0}^{\beta}
$$

The ratio of the model to the variable angle of internal friction uses new concepts of stresses and strain rates on the conjugate planes of greatest deviation. This allows us to use the apparatus of the theory of plastic flow to describe the process of deformation of the discrete medium not only in the boundary, but also in the preboundary state from a single position, which can be the basis for setting the "mixed" boundary problem of mechanics of soils.

\section{Conclusions}

The proposed defining relations of the model of a discrete medium with a variable angle of internal friction use new concept of stresses and deformations in conjugated planes, convenient for describing the plastic deformation of the discrete material. This allows us to use the theory of a plastic flow with a variable flow surface to describe the process of deformation of discrete materials both in the boundary and in the pre-boundary state by the same dependencies. The ratios operate with two variable parameters and the angle of greatest deviation $\rho$, which reflects the influence of internal friction on the deformation process of a discrete material, and the velocity of volumetric deformations $d \varepsilon_{0}^{s}$, taking into account the manifestation of dilatancy. Necessary for engineering calculations, the values of these parameters are determined by the results of testing macrosamples of the material for biaxial compression under the conditions of flat deformation. In general, the proposed defining ratios allow us to use the plastic flow theory apparatus with a variable flow surface to describe the stress-strained state of the discrete medium at all stages of loading.

\section{References}

1. Dorofieiev O. A. Reolohichni modeli seredovyshcha $\mathrm{z}$ suttievym vnutrishnim tertiam / O. A. Dorofieiev, V. V. Kovtun // Visnyk KhNU. - Tekhnichni nauky. - 2019. - № 3 (271). - S. 50-58.

2. Drucker D. C. Solid Mechanics and Plastic Analysis of Limit Design / D. C. Drucker, W. Prager. // Quarterly of Applied Mathematics. - 1952. - Vol. 10. - №2. - P. 157-165.

3. Malinin N. N. Prikladnaya teoriya plastichnosti i polzuchesti / N. N. Malinin. - M. : Mashinostroenie, 1975. $-397 \mathrm{~s}$

4. Kovtun V. V. Vyznachalni spivvidnoshennia mekhaniky dyskretnoho seredovyshcha / V. V. Kovtun // Visnyk Khmelnytskoho natsionalnoho universytetu. Tekhnichni nauky. - 2008. - №5. - S. 69-76.

5. Dorofeyev O. A. Estimation of the Stress-Strain State of a Discrete Medium by a Plastic Flow Model / O. A. Dorofeyev , V. V. Kovtun // Problems of Trybology. - 2019. - Vol. 24, № 3/93. - P. 29-38.

6. Kovtun V. V. Eksperymentalne obgruntuvannia vykhidnykh polozhen mekhaniky dyskretnoho seredovyshcha i vyznachennia rozrakhunkovykh parametriv modelei / V. V. Kovtun, O. A. Dorofieiev // Visnyk Khmelnytskoho natsionalnoho universytetu. Tekhnichni nauky. - 2011. - №3. - S. 20-28.

7. Kovtun V. V. Napruzhennia po potentsialnykh ploshchynkakh kovzannia u sypkomu seredovyshchi / V. V. Kovtun // Visnyk KhNU. - Tekhnichni nauky. - 2010. - № 1. - S. 7-12. 
8. Kovtun V. V. Deformatsii vzdovzh potentsialnykh linii kovzannia u sypkomu seredovyshchi / V. V. Kovtun, O. A. Dorofieiev. // Visnyk Khmelnytskoho natsionalnoho universytetu. Tekhnichni nauky. 2010. - №5. - S. 142-150.

9. Rabotnov Yu. N. Polzuchest elementov konstruktsiy / Yu. N. Rabotnov. - M. : Nauka, 1966. - 752 s.

10. Nikolaevskiy V. N. Sovremennyie problemyi mehaniki gruntov / V. N. Nikolaevskiy. // Opredelyayuschie zakonyi mehaniki gruntov. - M. : - 1975. - S. 210-227.

11. Stroganov A. S. Analiz ploskoy plasticheskoy deformatsii grunta / A. S. Stroganov // Inzhenernyiy zhurnal. - 1965. - \#4. - S. 734-742.

12. Malyishev M. V. O vliyanii srednego glavnogo napryazheniya na prochnost grunta i o poverhnostyah skolzheniya / M. V. Malyishev // Osnovaniya, fundamentyi i mehanika gruntov. - 1963. - \#1 . - S. 7-11.

13. Bugrov A. K. Napryazhenno-deformirovannoe sostoyanie osnovaniy i zemlyanyih sooruzheniy $s$ oblastyami predelnogo ravnovesiya : avtoref. dis. na poluchenie nauchn. stepeni d-ra tehn. nauk / A. K. Bugrov. - L. , 1980. - 49 s.

14. A. s. 1158925 SSSR. Pribor dlya issledovaniy svoystv grunta v usloviyah ploskoy deformatsii / V. V. Kovtun, V. G. Beznosyuk, N. A. Mazur. - \# 3673183/29-33; zayavl. 16.12.83; opublik. 30.05.85, Byul. \# 20.

15. A. s. 1141158 SSSR. Nagruzochnoe ustroystvo dlya ispyitaniy gruntov v priborah trehosnogo szhatiya / V. V. Kovtun, V. G. Beznosyuk, N. A. Mazur. - \# 3673169/29-33; zayavl. 16.12.83; opublik. 23.02.85, Byul. \# 7. 
Дорофєєв О.А., Ковтун В.В. Визначальні співвідношення реологічної моделі дискретного середовища зі змінним кутом внутрішнього тертя

В статті розглядаються визначальні співвідношення реологічної моделі дискретного середовища зі змінним кутом внутрішнього тертя, які відображають характерні особливості деформування дискретного матеріалу: вплив внутрішнього кулонового тертя i прояв дилатансії на усіх етапах від початку навантаження до настання граничного стану.

Співвідношення сформульовані у формі, що прийнята в теорії пластичного плину матеріалу зі змінною поверхнею плину. Це дозволило використати добре апробований апарат теорії пластичності твердого тіла для описання процесу деформування дискретного матеріалу.

Для формулювання співвідношень введено нові зручні для описання деформування дискретного матеріалу поняття про напруження і деформації, що виникають по особливих спряжених площинках. Визначальні співвідношення моделі дискретного середовища зі змінним кутом внутрішнього тертя використовують нові, зручні для описання пластичного деформування дискретного матеріалу поняття про напруження і деформації по спряжених площинах. Це дозволяє використати теорії пластичного плину зі змінною поверхнею плину для описання процесу деформування дискретних матеріалів як в граничному, так і у дограничному стані одними і тими ж залежностями.

Необхідні для використання моделі в інженерних розрахунках величини іiі змінних параметрів пропонується визначати за результатами спеціальних лабораторних випробувань макрозразків конкретного матеріалу на двовісне стиснення в умовах плоскої деформації.

Запропоновані визначальні співвідношення дозволяють використати апарат теорії пластичного плину зі змінною поверхнею плину для описання напружено-деформованого стану дискретного середовища на усіх етапах навантаження

Ключові слова: дискретне середовище; внутрішнє кулонове тертя; дилатансія. 